Egypt. J. of Appl. Sci., 35 (12) 2020

\title{
EFFECT OF POTASSIUM AND SOME MICRONUTRIENTS FOLIAR APPLICATION ON FLAX YIELD UNDER SANDY SOIL CONDITIONS
}

\author{
Taha A. Omar
}

Fiber crops Res. Dept., Field crops Res. Institute, ARC.

Key Words: flax, potassium, micronutrients, straw and seed yields, yield components, foliar application.

\section{ABSTRACT}

Two field experiments were performed at the Experimental Farm of Ismailia Agricultural Research station farm during 2014/15 and 2015/16 seasons. This study aimed to identify effectiveness of foliar spraying with three doses of potassium i.e. zero, 1.5 and $3 \mathrm{~g} / \mathrm{L}$ and three rates of micronutrients i.e. zero, 200 and $300 \mathrm{ppm}$ and their interaction in improving straw and seed yields and their components of Giza 9 flax cultivar under sandy soil conditions. The results indicated that increasing dose of potassium foliar spraying from zero up to $3 \mathrm{~g} / \mathrm{L}$ significantly increased straw, seed yields and their components. Increasing rate of micronutrients foliar application from zero up to $300 \mathrm{ppm}$ had significant effect on all characters studied except for fiber percentage appeared insignificant effect. Significant interaction between potassium and micronutrients foliar application were recorded in technical stem length, main stem diameter, straw yield/plant, straw yield/ fad and seed yield/ fad.

\section{INTRODUCTION}

Flax is still the main source of best fiber production in Egypt, which can be grown as a dual purpose crop for its seed and fiber. Great efforts had done to increase flax yield by the way of evolve new flax varieties and different agriculture treatments, but it still requires more these efforts. Since, the cultivated area of flax in Egypt reduced to 23721 fed. in 2020 (Annual Statistical Data, Ministry Of Agriculture, Cairo).

Sandy soils are one of the obstacles to the agricultural expansion for flax crop due to its lack of fertility and its poverty of nutrients, thus, it is necessary to search for foliar spraying with nutrients such as potassium and micronutrients foliar application for improving straw and seed yields in flax.

Potassium is known to play a vital role in photosynthesis, translocation of photosynthesis, regulation of plant pores (stomata), activation of plant catalysts (enzymes) and many other processes. So, many researches indicated that the positive effect of potassium application in enhancing growth and increasing seed, oil and fiber flax yields of them Hussein and Zedan (2008), Mousa and Hussein (2011), Bakry et al (2012), Omar (2013) and Bakry et al (2015 a) and Emam (2020). 
Foliar application which micronutrients is considered as one of the most important factors, as it had positive affect the productivity of flax. Iron, mangancese and zinc are key to chlorophyll formation, photosynthesis, respiration and enzyme activation. In this concern, Mousa et al (2010) showed that micronutrients foliar application was more effective on increasing plant height, technical length, straw, fiber and seed yields/ fad. Nofal et al (2011) revealed that foliar application by zinc at the rate of $2 \mathrm{~g} / \mathrm{L}$ caused significant increase for growth, fiber yield and seed yield over the control treatment. Bakry et al (2012) found that foliar application with $\mathrm{Zn}$ positively affected straw and seed yields and their components characters compared with control treatment. Tahir et al (2014) reported that foliar spraying flax plant with $\mathrm{Zn}$ at the rate of $3 \%$ bud initiation and after capsule filling stage significantly improved plant height, technical length fruiting branches, seed index, straw yield and seed yield. Bakry et al. (2015 a) revealed that zinc foliar application at the rate of 5\% gave the highest values of flax yield and it's components and quality.

Furthermore, Abd Eldaiem and Elmanzlawy (2016) indicated that foliar spraying with $\mathrm{Zn}$ at the rates of 250 and $500 \mathrm{ppm}$ significantly affected straw and seed yields and their components characters and produced the highest values. Abo- Marzoka and El- Borhamy (2018) showed that maximum values of plant height, fruiting zone length and technical length were obtained with foliar spraying 200ppm micronutrients mixture of $(\mathrm{Fe}+\mathrm{zn}+\mathrm{Mn})$ in addition, straw and seed yields and its components, fiber\% and oil $\%$.

Therefore, this study was aimed to find out the effect of foliar spraying with potassium and micronutrients on straw and seed yields and their components of flax plant under sandy soil conditions.

\section{MATERIALS AND METHODS}

The present work was done at the Experimental Farm of Ismailia Agric. Res. station farm, Ismailia Governorate, during the two successive seasons 2014/15 and 2015/16 on the first week of November in both seasons. The soil of the experimental site was sandy in texture. The physical and chemical of the soil are given in Table (1). These two trials were carried out in three replications using the strip plot design, horizontal strip was allocated by foliar spraying of potassium doses i.e. zero, 1.5 and $3 \mathrm{~g} / \mathrm{L}$ while vertical strip occupied by foliar spraying micronutrients i.e. zero, 200 and $300 \mathrm{ppm}$. The experimental unit area was $6^{2}$. The micronutrients mixture used in this case composed of $\mathrm{Zn}$, $\mathrm{Mn}$ and Fe. Potassium and micronutrients doses were applied twice after 40 and 60 days from sowing in spray volume at 200 liter water/fad, for each treatment in the first and second dates, respectively. Giza 9 cultivar seeds were sown at the rate of $60 \mathrm{~kg} / \mathrm{fed}$. 
Table (1): Some physical and chemical properties of the experimental site during 2014/2015 and 2015/2016 seasons.

\begin{tabular}{|c|c|c|}
\hline & $2014 / 2015$ & $2015 / 2016$ \\
\hline \multicolumn{3}{|c|}{ Physical characters } \\
\hline Coarse sand (\%) & 81.56 & 81.12 \\
\hline Fine sand (\%) & 7.57 & 7.35 \\
\hline Silt (\%) & 4.21 & 4.59 \\
\hline Clay $(\%)$ & 6.66 & 6.94 \\
\hline $\mathrm{Ca} \operatorname{Co3}(\%)$ & 2.62 & 2.68 \\
\hline Soil texture & Sandy & Sandy \\
\hline \multicolumn{3}{|c|}{ Chemical characters } \\
\hline $\mathbf{P H}$ & 7.7 & 7.74 \\
\hline EC dsm-1 & 1.26 & 1.30 \\
\hline $\mathrm{Ca}+2$ & 2.41 & 2.49 \\
\hline $\mathrm{Mg}+2$ & 1.18 & 1.12 \\
\hline $\mathrm{Na}+$ & 8.37 & 8.71 \\
\hline $\mathbf{K}+$ & 0.64 & 0.68 \\
\hline Hco3 & 5.82 & 5.87 \\
\hline Cl-- & 3.87 & 3.94 \\
\hline So 4 & 2.91 & 3.19 \\
\hline $\mathbf{N}$ & 21.7 & 21.3 \\
\hline $\mathbf{P}$ & 7.54 & 7.54 \\
\hline K & 3.65 & 4.8 \\
\hline
\end{tabular}

At harvest time, ten guarded plants were taken randomly from each plot to record the following characters: Total plant length $(\mathrm{cm})$, technical stem length $(\mathrm{cm})$, main stem diameter $(\mathrm{mm})$, straw yield/ plant $(\mathrm{g})$ straw yield/fad (ton), fiber\%, fiber fineness according to Radwan and Momtaz (1966), number of capsules/plant, number of seeds/capsule, number of seeds/plant, seed index (g), seed yield/ plant $(\mathrm{g})$ and seed yield/fad $(\mathrm{kg})$. Oil\% was determined as average of two random seed samples/plot using Soxhelt apparatus (A. O. A. C Society, 1995).

The combined analyses of variance (across the two seasons) were done according to Snedecor and Cochran (1989) after confirmation of homogeneity test. Mean values were compared at the 0.05 level of significance and used the least significant difference test (LSD).

\section{Straw yield and its components:}

\section{RESULTS AND DISCUSSION}

\section{Potassium effects:}

Mean values of straw yield and its components from the combined data of two successive seasons as affects by potassium and micronutrients foliar application were presented in Table (2). Results showed that straw yield and its components i.e. total plant height, technical stem length, main stem diameter, straw yield/plant, straw yield/fad, fiber percentage and fiber fineness, were significantly responded to potassium fertilizer doses. It is clearly evident that increasing potassium doses from zero up to $3 \mathrm{~g} / \mathrm{L}$ 
significantly increased straw yield and its components spraying potassium at the rate of $3 \mathrm{~g} / \mathrm{L}$ was associated with the highest values of total plant length (110.97), technical stem length (100) main stem diameter (2.46), straw yield/plant (2.28), straw yield/fad (4.09), fiber\% (18.57) and fiber fineness (222.5). these results could be attributed to the important role of potassium in stimulating growth of merestimatic tissue which produce more cells and more vegetative growth. These results are in harmony with these obtained by Hussein and Zedan (2008), Mousa and Hussein (2011), Bakry et al (2012), Omar (2013), Bakry et al (2015 a) and Emam (2020).

Table (2): Means of straw yield and its components as affected by potassium $(K)$ and micronutrient $(M)$ foliar application (combined data of 2014 / 15 and 2015/16 seasons.

\begin{tabular}{|c|c|c|c|c|c|c|c|}
\hline Characters & $\begin{array}{l}\text { Total } \\
\text { plant } \\
\text { length } \\
(\mathrm{cm}) \\
\end{array}$ & $\begin{array}{c}\text { Technical } \\
\text { stem } \\
\text { length } \\
\text { (cm) } \\
\end{array}$ & $\begin{array}{c}\text { Main stem } \\
\text { diameter } \\
(\mathbf{m m})\end{array}$ & $\begin{array}{c}\text { Straw } \\
\text { yield/plant } \\
\text { (g) }\end{array}$ & $\begin{array}{c}\text { Straw } \\
\text { yield/fad } \\
\quad \text { (ton) }\end{array}$ & Fiber \% & $\begin{array}{c}\text { Fiber } \\
\text { fineness } \\
\text { (N.m) }\end{array}$ \\
\hline \multicolumn{8}{|l|}{ Potassium } \\
\hline Ko $=$ zero & 106.76 & 95.49 & 2.22 & 1.64 & 3.53 & 15.88 & 195.68 \\
\hline $\mathrm{K} 1=1.5 \mathrm{~g} / \mathrm{L}$ & 108.81 & 98.96 & 2.34 & 1.97 & 3.73 & 17.79 & 209.51 \\
\hline$K 2=3 g / L$ & 110.97 & 100.69 & 2.46 & 2.28 & 4.09 & 18.57 & 222.54 \\
\hline LSD 0.05 & 0.21 & 0.34 & 0.01 & 0.03 & 0.07 & 2.03 & 1.28 \\
\hline \multicolumn{8}{|l|}{ Micronutrients } \\
\hline M0 $=$ zero & 107.93 & 97.39 & 2.31 & 1.85 & 3.70 & 16.21 & 204.43 \\
\hline M1 = 200ppm & 108.81 & 98.49 & 2.33 & 1.96 & 3.76 & 17.69 & 209.76 \\
\hline M2 $=300 \mathrm{ppm}$ & 109.81 & 99.29 & 2.38 & 2.07 & 3.89 & 18.34 & 213.53 \\
\hline LSD 0.05 & 0.38 & 0.28 & 0.010 & 0.02 & 0.03 & N.S & 1.35 \\
\hline $\begin{array}{l}\text { Interactions } \\
\mathrm{K} \times \mathbf{M}\end{array}$ & N.S & 0.40 & 0.02 & 0.03 & 0.05 & N.S & N.S \\
\hline
\end{tabular}

Micronutrients effects:

As shown in Table (2), the seven traits of flax under study differed significantly differences due to spray of micronutrients mixture were detected for straw yield/plant and its components except of fiber percentage which appeared opposite trend. It is clear that micronutrients application with $300 \mathrm{ppm}$ was significantly increased in total plant length, technical stem length, main stem diameter, straw yield/plant, straw yield/fad and fiber fineness, but it led to insignificant increase in fiber percentage character. Similar results were reported by Mousa et al (2010), Nofal et al (2011), Bakry et al (2012), Tahir et al (2014), Bakry et al (2015 a), Abd El Daiem and Amal Elmanzlawy (2016), Abo- Marzoka and El-Bohamy (2018) and Emam (2020).

\section{Interaction effects}

The interaction between potassium and micronutrients foliar application had a significant effect on technical stem length, main stem diameter, straw yield/plant and straw yield/fad as average of the two seasons (Table 3), The highest interaction of potassium foliar application at a dose of $3 \mathrm{~g} / \mathrm{L}$ with micronutrients foliar application at a rate of 300 ppm were observed for technical stem length $(101.57 \mathrm{~cm})$, main stem 
diameter $(2.48 \mathrm{~cm})$, straw yield/plant $(2.36 \mathrm{~g})$ and straw yield/fed $(4.18$ ton). These results indicated that potassium and micronutrients foliar application had successfully interacted, which reflected in the improvement of previous characters . On the other hand, the interaction between potassium and micronutrients foliar application on total plant length, fiber $\%$ and fiber fiteness had no significant effect.

Table (3): The significant interaction between potassium $(K)$ and micronutrient $(M)$ on straw yield and its components from the combined analysis.

\begin{tabular}{|c|c|c|c|c|}
\hline Interaction & $\begin{array}{c}\text { Technical stem } \\
\text { length }\end{array}$ & $\begin{array}{c}\text { Main stem } \\
\text { diameter }\end{array}$ & $\begin{array}{c}\text { Straw yield / } \\
\text { plant }\end{array}$ & $\begin{array}{c}\text { Straw yield / } \\
\text { fad }\end{array}$ \\
\hline K0 x M0 & 94.18 & 2.19 & 1.52 & 3.47 \\
\hline K0 x M1 & 95.72 & 2.22 & 1.65 & 3.52 \\
\hline K0 x M2 & 96.58 & 2.26 & 1.76 & 3.59 \\
\hline K1 x M0 & 98.13 & 2.30 & 1.86 & 3.66 \\
\hline K1 x M1 & 99.1 & 2.32 & 1.98 & 3.66 \\
\hline K1 x M2 & 99.65 & 2.39 & 2.07 & 3.88 \\
\hline K2 x M0 & 99.85 & 2.44 & 2.20 & 3.99 \\
\hline K2 x M1 & 100.67 & 2.45 & 2.27 & 4.10 \\
\hline K2 x M2 & 101.57 & 2.48 & 2.36 & 4.18 \\
\hline LSD 0.05 & 0.40 & 0.02 & 0.03 & 0.05 \\
\hline
\end{tabular}

\section{Seed yield and its components:}

\section{Potassium effects:}

Mean values of seed yield and its components from the combined data of two successive seasons as affected by potassium and micronutrients folir application were presented in Table (4). Potassium fertilizer doses as foliar spray had significant effect on all seed yield and its components under study. The potassium as foliar spray at dose of $3 \mathrm{~g} / \mathrm{L}$ gave highest values of number of capsules / plant, number of seeds / capsule, number of seeds / plant, seed index, seed yield / plant, seed yield / fed and oil percentage which recorded 15.03 capsule, 8.41 seed, 126.26 seeds, $5.62 \mathrm{~g}, 0.49 \mathrm{~g}, 404.47 \mathrm{~kg}$ and 34.78 $\%$, respectively, when compared with the control treatment (zero, K0). These results could be discussed on the important role of potassium in stimulating biological process in plant as enzymes activity, respiration photosynthesis, chlorophyll creation and water relationships. These results are in agreement with those obtained by Hussein and Zedan (2008), Mousa and Hussein (2011), Bakry et al. (2012), Omar (2013) and Abd El-Daiem, Bakry et al (2015 a) and Emam (2020).

\section{Micronutrients effects:}

The results given in Table (4) indicated that micronutrients foliar application had significant effect on seed yield and its components. It is clear that micronutrients foliar application with $300 \mathrm{ppm}$ significantly increased in number of capsules/plant (13.77 capsule), number of seeds/capsule (7.91 seed), number of seeds/plant (109.83 seed), seed index (5.47 g), seed yield/plant (0.50 g), seed yield/ fed (397.69 kg) and oil percentage (34.22). While, control treatment gave the lowest values. Similar results were 
reported by Mousa et al. (2010), Nofal et al. (2011), Bakry et al. (2012), Tahir et al. (2014), Bakry et al. (2015b), Abd Eldaiem, and Elmanzlawy (2016), Abo- Marzoka and El-Borhamy (2018) and Emam (2020).

Table (4): Means of seed yield and its components as affected by potassium (K) and micronutrients (M) foliar application (combined data of 2014 / 15 and 2015 / 16 seasons)

\begin{tabular}{|c|c|c|c|c|c|c|c|}
\hline Treatments & $\begin{array}{c}\text { No. of } \\
\text { capsules / } \\
\text { plant }\end{array}$ & $\begin{array}{l}\text { No. of } \\
\text { seeds / } \\
\text { copsle }\end{array}$ & $\begin{array}{c}\text { No. of } \\
\text { seeds / } \\
\text { plant }\end{array}$ & $\begin{array}{c}\text { Seed } \\
\text { index }(g)\end{array}$ & $\begin{array}{l}\text { Seed yield/ } \\
\text { plant (g) }\end{array}$ & $\begin{array}{c}\text { Seed } \\
\text { yield/ fad } \\
(\mathrm{kg})\end{array}$ & Oil \% \\
\hline \multicolumn{8}{|l|}{ Potassium } \\
\hline Ko = zero & 11.02 & 6.86 & 75.68 & 5.17 & 0.44 & 379.40 & 33.69 \\
\hline $\mathrm{K} 1=1.5 \mathrm{~g} / \mathrm{L}$ & 13.12 & 7.64 & 100.38 & 5.34 & 0.47 & 392.79 & 34.27 \\
\hline$K 2=3 g / L$ & 15.03 & 8.41 & 126.26 & 5.62 & 0.49 & 404.47 & 34.78 \\
\hline LSD 0.05 & 0.42 & 0.07 & 5.11 & 0.12 & 0.02 & 2.28 & 0.07 \\
\hline \multicolumn{8}{|l|}{ Micronutrients } \\
\hline M0 $=$ zero & 12.36 & 7.38 & 92.23 & 5.27 & 0.40 & 386.35 & 34.09 \\
\hline M1 $=200 p p m$ & 13.04 & 7.61 & 100.26 & 5.39 & 0.45 & 392.62 & 34.22 \\
\hline M2 $=300 \mathrm{ppm}$ & 13.77 & 7.91 & 109.83 & 5.47 & $\mathbf{0 . 5 0}$ & 397.69 & 34.43 \\
\hline LSD 0.05 & 0.26 & 0.10 & 2.98 & 0.12 & 0.02 & 1.43 & 0.04 \\
\hline $\begin{array}{l}\text { Interactions } \\
\text { K x M }\end{array}$ & N.S & N.S. & N.S & N.S & N.S & 2.05 & N.S \\
\hline
\end{tabular}

\section{Interaction effects:}

The interaction between potassium and micronutrients foliar application had a significant effect on seed yield/fad (Table 5). The maximum value 411.73 was obtained from the interaction of potassium foliar spraying at a dose of $3 \mathrm{~g} / \mathrm{L}$ with micronutrients foliar application of $300 \mathrm{ppm}$. On the other hand, the interaction had insignificant effect on the remaining characters.

Table (5): The significant interaction between potassium and micronutrients on seed yield/ fad from the combined analysis

\begin{tabular}{|c|c|}
\hline Interaction & Seed yield $/$ fad \\
\hline $\mathbf{K}_{\mathbf{0}} \times \mathbf{M}_{\mathbf{0}}$ & $\mathbf{3 7 0 . 7 7}$ \\
\hline $\mathbf{K}_{\mathbf{0}} \times \mathbf{M}_{1}$ & $\mathbf{3 8 1 . 4 2}$ \\
\hline $\mathbf{K}_{\mathbf{0}} \times \mathbf{M}_{2}$ & $\mathbf{3 8 6 . 0 2}$ \\
\hline $\mathbf{K}_{1} \times \mathbf{M}_{\mathbf{0}}$ & $\mathbf{3 8 9 . 8 3}$ \\
\hline $\mathbf{K}_{1} \times \mathbf{M}_{1}$ & $\mathbf{3 9 3 . 2 0}$ \\
\hline $\mathbf{K}_{1} \times \mathbf{M}_{2}$ & $\mathbf{3 9 5 . 3 3}$ \\
\hline $\mathbf{K}_{2} \times \mathbf{M}_{\mathbf{0}}$ & $\mathbf{3 9 8 . 4 5}$ \\
\hline $\mathbf{K}_{\mathbf{2}} \times \mathbf{M}_{1}$ & $\mathbf{4 0 3 . 2 3}$ \\
\hline $\mathbf{K}_{2} \times \mathbf{M}_{2}$ & $\mathbf{4 1 1 . 7 3}$ \\
\hline $\mathbf{L S D ~ 0 . 0 5}$ & $\mathbf{2 . 0 5}$ \\
\hline
\end{tabular}

\section{CONCLUSION:}

In the light of the obtained results of this study it could be concluded that for achieve the maximum straw and seed yields, it may be recommended to encourage expansion of flax variety Giza 9 by foliar 
spraying with potassium at a dose of $3 \mathrm{~g} / \mathrm{L}$ with the mixture of micronutrients at a rate of $300 \mathrm{ppm}$ under sandy soil conditions.

\section{REFERENCES}

Abd Eldaiem, M. A. M. and Amal M. Elmanzlawy (2016). Influence of foliar spraying with Zinc, macro and micro- elements and gibberellic acid on productivity and seed quality of flax. Egypt J. Appl. Sci., 31 (1): 55-66.

Abo- Marzoka, E. A. and Amal M. A. El- Borhamy (2018). Response of flax plant to foliar spray by urea and some of micronutrients mixture under different nitrogen levels. Alex. J. Agric. Sci., 63: (4): $251-261$.

A. O. A. C. (1995). Official Methods of Analysis $16^{\text {th }}$ ed. Association of Official Analytical Chemists. Washington, D. C., U. S. A.

Bakry , B. A. ; M. M. Tawfik ; B. B. Mekki and M. S. Zeidan (2012). Yield and yield components of three flax cultivars in response to foliar application with $\mathrm{Zn}, \mathrm{Mn}$ and Fe under Newly reclaimed sandy soil conditions. American- Eurasian J. Agric \& Environ. Sci., 12 (8): 1075- 1080.

Bakry, A. B. ; O. A. Nofal ; M. S. Zeidan and M. Hozayn (2015 a). Potassium and zinc in relation to improve flax varieties yield and yield components as grown under sandy soil conditions. Agricultural sciences, 6 (1):152-158.

Bakry, A.B. ; Shaimaa Shedeed and O.A. Nofal (2015 b). Production and quality of two flax varieties as affected by foliar application of silicon fertilizer under sandy soil conditions. Res. J. of Pharmaceutical, Biological and Chemical Sciences, 6 (5): 181188.

Emam, S. (2020). Estimation of straw, seed and oil yields for flax plants ( Linum usitatissimum L.) cultivars of foliar application of $\mathrm{mn}$, fe and $z n$ under dry environment. Egyptian Journal of Agronomy, 42(1): 35-46.

Hussein, M. M. M. and S. Z. A. Zedan (2008). Yield and quality of two flax varieties as affected by foliar spraying with potassium doses and nitrogen levels under sandy soil conditions. J. Agric. Sci., Mansoura Univ., 33 (6): 3937- 3952.

Mousa, M. A. and M. M. M. Hussein (2011). The effect of potassium fertilizer levels on growth, yield quantity and quality for some flax (linum usitatissimum, L.) varieties. Egypt J. Appl. Sci., 26 (9): 511-522.

Mousa, M. A. ; Eman A. E. El- Kady and Z. S. Zedan (2010). Effect of nitrogen fertilizers and some micronutrients on flax yield and chemical composition characters. J. plant production, Mansoura Univ., 1 (5): 713- 720. 
Nofal, O. A. ; M. S. Zedian and B. A. Bakry (2011). Flax yield and quality traits as effected by Zinc foliar application under newly reclaimed sandy soils. J. of App. Sci. Res., 7 (9): 1361- 1367.

Omar, T. A. (2013). Effect of potassium and magnesium as foliar application on yield, yield components and yield analysis for two new flax varieties in sandy soil. Zagazig J. Agric. Res., 40 (3): 371- 385 .

Radwan, S. R. and A. Momtaz (1966). The technological properties of flax fibers and methods of estimating them. El- felaha J., 46 (5): 466- 476 (In Arabic).

Snedecor, G. W. and W. G. Cochran (1989). Statistical Methods $8^{\text {th }}$ ed., Iowa State Univ. Press Ames Iowa, USA.

Tahir, M.; M. Irfan and A. Ur- Rehman (2014). Effect of foliar application of Zinc on yield and oil contents of flax. Pakistan J. Agric. Res., 27 (4): 287- 295.

تأثير الرش بالبوتاسيوم ويعض العناصر الصغرى على محصول الكتان تحت

$$
\text { ظروف الأرض الرملية }
$$

طه أحمد عمر

قسم بحوث محاصيل الألياف- معهد بحوث الححاصيل الحقلية- مركز البحوث الزراعية

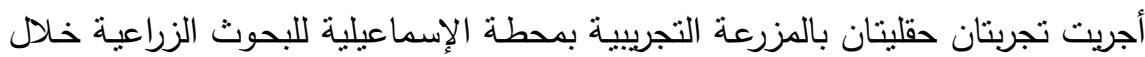

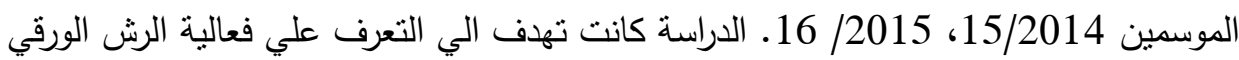

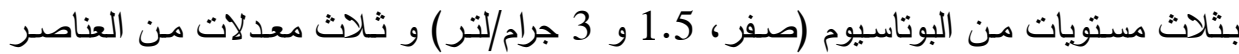

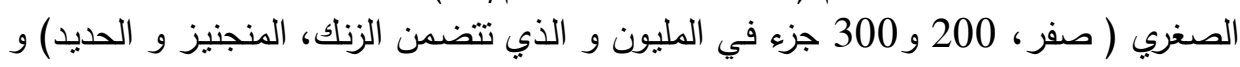

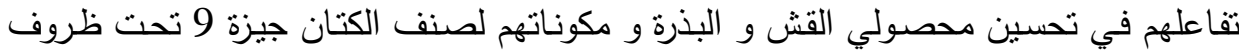

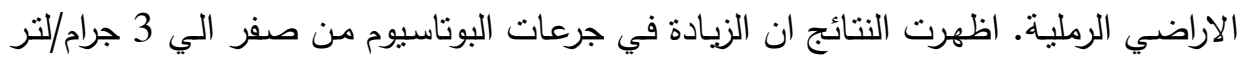

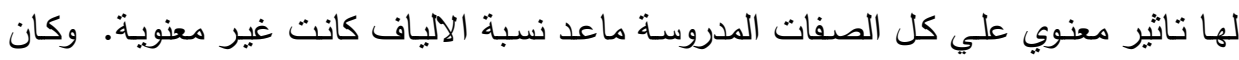
هناك تفاعل معنوى بين الرش بالبوتاسيوم والعناصر الصغرى على الطول الفعال، سمك الساق

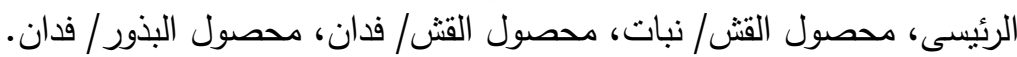

